\title{
Hydro-Geochemical Analysis of Bhima River in Gulbarga District, Karnataka State, India.
}

\author{
Shivasharanappa ${ }^{1 *}$ and Anand Yalkpalli ${ }^{2}$ \\ ${ }^{1}$ Associate Professor, Dept of Civil Engineering, P. D. A. College of Engineering (Autonomous Institution) Gulbarga, \\ Karnataka State, India, \\ 2. Lecturer, Dept of Civil Engineering, Basavakalyan College of Engineering, Basavakalyan, Karnataka State, India,
}

\begin{abstract}
The study area in Gulbarga District, Karnataka State, India, is selected to discuss the surface water quality of Bhima River on irrigation and human health, where the agriculture is the main livelihood of rural people and the surface water is the main source for irrigation and drinking. Surface water collected during pre-monsoon for two months from three sampling points in the area were analyzed for $\mathrm{pH}$, Total Dissolved Solids, Total Hardness, Calcium, Magnesium, Chloride, Nitrate, Sulphate, DO, BOD, Alkalinity, Sodium, Potassium and Fluoride. The chemical relationships in Piper's diagram and Gibb's diagram suggest that the surface water mainly belong to carbonate hardness (secondary alkalinity) and non-carbonate hardness (primary salinity) and are controlled by Rock dominance, respectively, due to the influence of semi-arid, gentle slope, greater water-rock interaction and anthropogenic activities. US salinity Laboratory and \% $\mathrm{Na}^{+}$ used for evaluating the water quality for irrigation suggest that the majority of the sampling points of surface water are moderate for irrigation in pre-monsoon. These conditions are caused due to leaching of salts from the overlying materials by infiltration recharge waters. A management plan is a must for sustainable development of the area.
\end{abstract}

Keywords: Surface water quality characteristics, Drinking water standards, Piper's diagram, Gibb's diagram, Chadha's diagram, US Salinity diagram

\section{INTRODUCTION}

Surface water is used for domestic, industrial, water supply and irrigation all over the world. In the last few decades, there has been a tremendous increase in the demand for fresh water due to rapid growth of population and the accelerated pace of industrialization. Human health is threatened by most of the agricultural development activities particularly in relation to excessive application of fertilizers [1]. According to World Health Organization (WHO), about $80 \%$ of all the diseases in human beings are caused by water [2]. Although any environmental impact could be either beneficial or adverse to the environment. In environmental analysis, impacts are historically considered only to be of adverse type caused by our developmental activities. Impacts can be generally categorized as primary, secondary or tertiary. Primary impacts are those caused directly by project inputs such as loss of forests, or changing of a river regime due to the construction of a dam etc. As such primary impacts can be attributed directly to a project activity. They are usually easy to measure. Secondary impacts are those caused by project outputs such as water flow regulation and channelization. In other words, they are indirectly attributed to the project activity. If one of the project outputs is availability of irrigation water, secondary impacts could be more severe than primary impacts and unfortunately, often more difficult to predict and measure [3]. Secondary impacts in turn may lead to tertiary impacts. It should be noted that the distinction between primary, secondary and tertiary impacts could often be arbitrary. Various types of water related activities can cause beneficial or adverse impacts on the environment, water channelization, flood land alteration and changes in land use patterns. In recent years continuous growth in pollution, rapid industrialization and accompanying technologies involving waste disposal has endangered the very existence of human race. Eventually the rate of clearance of forests for the purpose of different land uses is far higher than the methods that are implemented for afforestation. Among the different types of pollution, water pollution is one of the major causes, which creates immense public health hazards. Surface water quality is as important as the quantity. Poor quality of water adversely affects the plant growth and human health. Adverse conditions increase investment in irrigation and health, and decrease agricultural production, which, in turn, reduces agrarian economy and retards improvement in the living conditions of rural people. Unsustainable development is the result.

1.1. The main objectives of the present study are the following:

i. Physical, Chemical and Biological analysis of surface water samples collected during study period [4].

ii. Quality of water for drinking purpose by BIS and WHO standards [5, 6].

iii. Geochemical Analysis [7] with the help of Piper's, Gibb's, Chadha's and US Salinity Diagram is worked out for predicting irrigation water quality. 
IOSR Journal of Engineering

Apr. 2012, Vol. 2(4) pp: 862-882

\section{MATERIALS AND METHODS}

The Bhima River originates in Bhimashankar hills near Karjat on the western side of Western Ghats, known as Sahyadri, in Maharashtra state in India. Bhima River flows southeast for $725 \mathrm{~km}$ through Maharashtra and Karnataka states. Bhima River is the most important tributary of the Krishna River, which is one of the two majors rivers in Maharashtra, the other being Godavari River. Nira confluences with Bhima in Narsingpur, Solapur district of Maharashtra State. The banks of Bhima River are densely populated and form a fertile agricultural area. The river is prone to flooding due to heavy rainfall during the monsoon season. The proposed area under study i.e. Bhima river is located $25 \mathrm{~km}$ away from the Gulbarga City on national highway number 218. The study area Gulbarga is the divisional Head Quarters of the Six Revenue Districts of Bidar, Gulbarga, Yadgir, Raichur, Koppal and Bellary of Karnataka State, India. It is situated on Mumbai - Chennai section of the central railway and is at a distance of $640 \mathrm{~km}$ away from Bangalore city. It has sufficiently developed in the fields of education and industries. This divisional place is also having its own University situated on Sedam Road. The city has All India Radio Station and Television Transmitting Centre. Gulbarga is also a pilgrimage centre with important religious centers of Shri Sharanabasaveshwar Temple, Hazarat Khaja Bande Nawaz Darga, Methodist Church and Buddha Vihar. Gulbarga is situated at Latitude $17^{\circ} 40^{\prime} \mathrm{N}$ and longitude $76^{\circ} 80^{\prime} \mathrm{E}$ as shown in Figure 1. It has a general slope from North-West to South-East. Gulbarga lies between the contours $1570 \mathrm{~m}$ and $1460 \mathrm{~m}$ and the average above the mean sea level is about $454 \mathrm{~m}$. Population of the District as per 2011 census is 2564892 with an average population density of 233 per $\mathrm{Km}^{2}$. Land use pattern has a significant influence on the quality and quantity of runoff available from it. It plays an important role in determining the various hydrological phenomena like infiltration, overland flow, evaporation and interception. Krishna and Bhima Rivers drain in this district and constitute the two major river basins of the district. Kagina and Amarja are the two sub basins of Bhima River, which occur within the geographical area of the district. The southwest monsoon sets in the middle of June and extends till the end of September. Bulk of the annual rainfall occurs during this season, which constitutes over $75 \%$ of the annual rainfall. Significant rainfall occurs during the winter monsoon owing to north-eastern monsoon, which constitutes $15 \%$ of the annual rainfall. Normal rainfall of the district is 777 $\mathrm{mm}$; actual rainfall is $881.10 \mathrm{~mm}$ and average annual rainfall $832.3 \mathrm{~mm}$. Gulbarga district lies in the northern plains of Karnataka and has semi arid type of climate. Dry climate prevails for most part of the year. December is the coldest month with mean daily maximum and minimum temperatures being $29.5^{\circ} \mathrm{C}$ and $15^{\circ} \mathrm{C}$ to $10^{\circ} \mathrm{C}$ respectively. During peak summer, temperature shoots up to $47^{\circ} \mathrm{C}$. Relative humidity varies from $26 \%$ in summer to $62 \%$ in winter. The soil types in the district are Deep Black, Medium Black Soil, and Lateritic Soil. The Deep and Medium Black soil covers practically the entire districts area, except a small portion towards the northern part of the district. Black soil has been derived from basaltic rocks and varies from color from medium to deep black. Its thickness varies from 0.5 to $3.6 \mathrm{~m}$. Infiltration rate of shallow, medium and deep black soil is moderate to poor. All reagents were analytical grade and solutions were made of distilled water. Various water quality parameters such as hardness, alkalinity, BOD, DO etc., were determined using standard analytical methods. The instruments used were calibrated before use for observing readings. The repeated measurements were made to ensure precision and accuracy of results. Surface water samples are collected from three points. For two kilometers length of flow three sampling points were selected. $S_{1}$ upstream of village Hipperga, $S_{2}$ near village Hipperga and $S_{3}$ downstream of village Hipparga. The water samples were collected in the morning at 08:00 to 10:00 am for a period of 2 months successively i.e., April 2011 to May 2011. Two and half liters of surface water samples were collected in white colored plastic containers and were transferred to the laboratory at the earliest. The samples were analyzed for physical, chemical and biological parameters as per standard procedural methods [4] are then compared with WHO and BIS water quality standards $[5,6]$. 


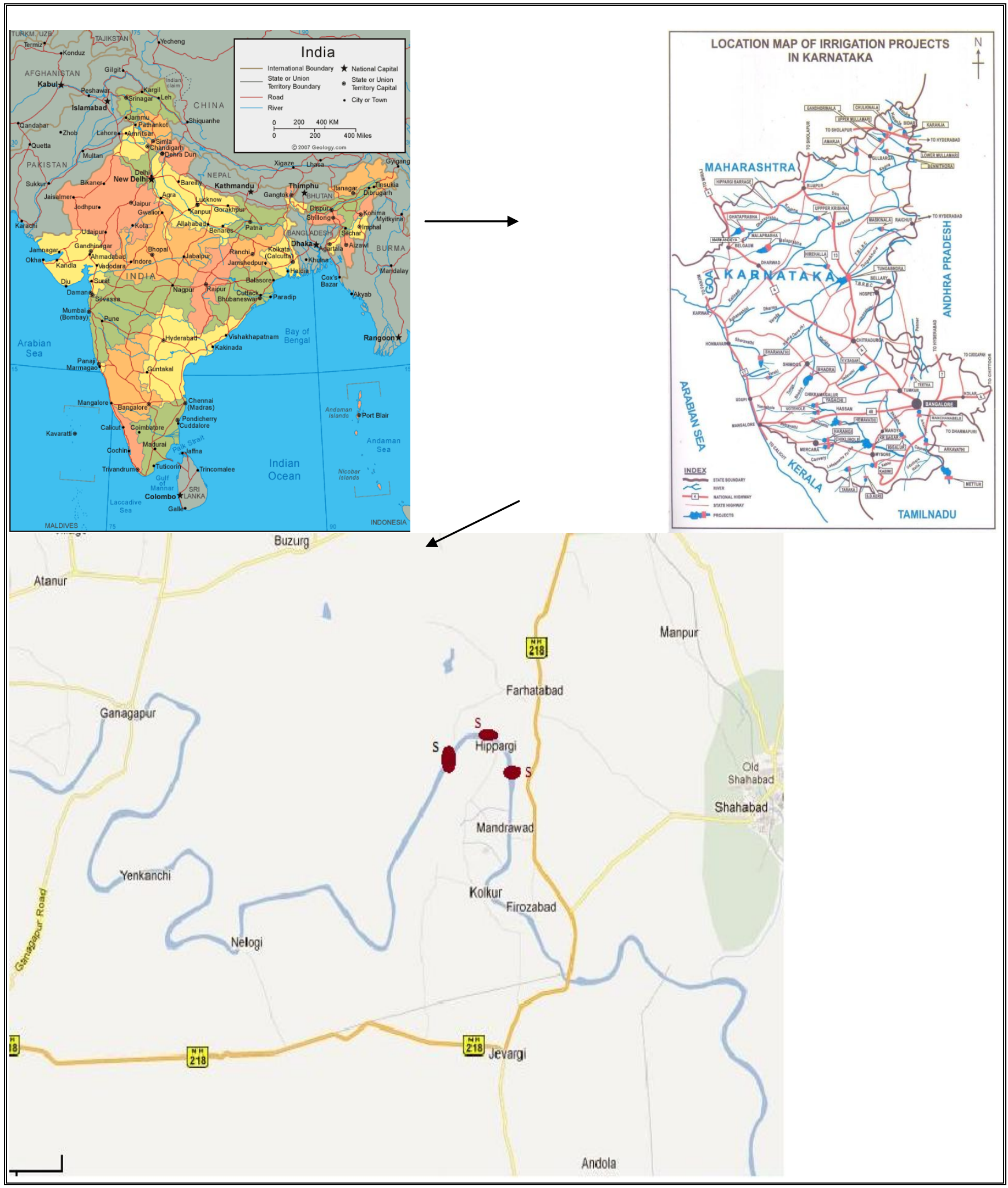

Fig. 1: Showing the Location of sampling points on Bhima River 
IOSR Journal of Engineering

Apr. 2012, Vol. 2(4) pp: 862-882

\section{RESULTS AND DISSCUSSIONS}

In this chapter for the purpose of revealing the surface water quality of three sampling points of the study area have been established by determining the physical, chemical and biological characteristics as per standard methods [4]. The $\mathrm{pH}$ values of the samples varied between 6.30 to 7.90 at sampling point (upstream), 7.42 to 8.14 at sampling point (near village) and 7.20 to 8.05 at sampling point (downstream). It is observed that the $\mathrm{pH}$ of the surface water was slightly alkaline and only minor fluctuation in $\mathrm{pH}$ was recorded. The $\mathrm{pH}$ levels were within the limits set by the WHO and BIS. The permissible total dissolved salts for drinking water is $500 \mathrm{mg} / \mathrm{L}$. In the absence of potable water source the permissible limit is up to $2000 \mathrm{mg} / \mathrm{L}$. It is found from the analysis; all the water samples are within the maximum limit of $2000 \mathrm{mg} / \mathrm{L}$. The range of TDS levels in the study area is $780.30 \mathrm{mg} / \mathrm{L}$ to $1020.0 \mathrm{mg} / \mathrm{L}$ at sampling point (upstream), $832.10 \mathrm{mg} / \mathrm{L}$ to $1160.30 \mathrm{mg} / \mathrm{L}$ at sampling point (near village) and $805.70 \mathrm{mg} / \mathrm{L}$ to $988.0 \mathrm{mg} / \mathrm{L}$ at sampling point (downstream). High values of TDS in surface water are generally not harmful to human beings but high concentration of these may affect persons who are suffering from kidney and heart diseases, also water containing high solids may cause laxative or constipation effects. Natural hardness of water depends upon the geological nature of the drainage basin and mineral levels in natural water. The total hardness ranged between $630.90 \mathrm{mg} / \mathrm{L} \mathrm{to} 800.40 \mathrm{mg} / \mathrm{L}$ at sampling point (upstream), $694.0 \mathrm{mg} / \mathrm{L}$ to $840.0 \mathrm{mg} / \mathrm{L}$ at sampling point (near village) and $647.0 \mathrm{mg} / \mathrm{L}$ to $791.70 \mathrm{mg} / \mathrm{L}$ at sampling point (downstream). Hardness is little more in this river water, a separate Geochemical/Hydro geochemical analysis is a must to arrive at the hardness nature of this river water. The magnesium hardness exceeds in all the samples, it ranges from $100.70 \mathrm{mg} / \mathrm{L}$ to $179.0 \mathrm{mg} / \mathrm{L}$ at sampling point (upstream), $86.0 \mathrm{mg} / \mathrm{L}$ to $160.0 \mathrm{mg} / \mathrm{L}$ at sampling point (near village) and 131.48 $\mathrm{mg} / \mathrm{L}$ to $246.70 \mathrm{mg} / \mathrm{L}$ at sampling point (downstream). There are no known cases of magnesium poisoning. At large oral doses of magnesium may cause vomiting and diarrhea. High doses of magnesium in medicine and food supplements may cause muscle slackening, nerve problems, depressions and personality changes. The chloride content increases normally as the mineral content increases. The chloride level ranged between $34.50 \mathrm{mg} / \mathrm{L}$ to $153.10 \mathrm{mg} / \mathrm{L}$ at sampling point (upstream), $90.0 \mathrm{mg} / \mathrm{L}$ to $274.0 \mathrm{mg} / \mathrm{L}$ at sampling point (near village) and $94.60 \mathrm{mg} / \mathrm{L}$ to $170.80 \mathrm{mg} / \mathrm{L}$ at sampling point (downstream). Here it is observed that the chloride concentration in the samples fall well within the permissible limit. The total alkalinity of the water samples was below the permissible and desirable criteria for domestic water supply. The observed alkalinity was due to methyl orange alkalinity since phenolphthalein alkalinities were zero in all the water sampling points. Consequently, the water samples are not polluted with respect to alkalinity. Dissolved Oxygen present in drinking water adds taste and it is highly fluctuating factor in water. In this study dissolved oxygen content varied in a limited range of $5.91 \mathrm{mg} / \mathrm{L}$ to $8.97 \mathrm{mg} / \mathrm{L}$ at sampling point (upstream), $1.45 \mathrm{mg} / \mathrm{L}$ to $8.14 \mathrm{mg} / \mathrm{L}$ at sampling point (near village) and $5.23 \mathrm{mg} / \mathrm{L}$ to $5.92 \mathrm{mg} / \mathrm{L}$ at sampling point (downstream). The Biological Oxygen Demand (BOD) gives an idea of the quantity of biodegradable organic matter present in an aquatic system which is subjected to aerobic decomposition by microbes. Accordingly it provides a direct measurement of the state of pollution. The concentration of BOD ranged from $3.21 \mathrm{mg} / \mathrm{L}$ to $8.88 \mathrm{mg} / \mathrm{L}$ at sampling point (upstream), $0.77 \mathrm{mg} / \mathrm{L}$ to $7.5 \mathrm{mg} / \mathrm{L}$ at sampling point (near village) and $1.47 \mathrm{mg} / \mathrm{L}$ to $4.12 \mathrm{mg} / \mathrm{L}$ at sampling point (downstream). The concentration of fluoride in drinking water is critical considering health problems related to teeth and bones. High fluoride concentration causes dental fluorosis and skeletal fluorosis. Whereas the absence or low concentration of fluoride concentration (less than $0.5 \mathrm{mg} / \mathrm{L}$ ) cause tooth decay. The recommended desirable limit of fluoride is $1 \mathrm{mg} / \mathrm{L}$. In present study area, fluoride content in all sampling points is well within the permissible standards. The sulphate and nitrate concentrations of all three sampling points are well within the permissible standards. The Most Probable Number (MPN) is a parameter, which indicates the presence of coli form bacterial pollution in the water samples. Presence of coli form also indicates the possibility of presence of other pathogenic micro-organisms and further indicates the possibility of contamination of the water source with sewage. During the study period, the MPN ranged from minimum of 3/100 ml to a maximum of 64/100 ml at sampling point (upstream), 7/100 ml to 120/100 ml at sampling point (near village) and $7 / 100 \mathrm{ml}$ to $120 / 100 \mathrm{ml}$ at sampling point (downstream). The MPN index values at all the sampling stations are high; this shows that water is not fit for drinking as it is. Disinfection is necessary.

Table 1: Normal Statistics of Water Quality Parameters of Surface Water at sampling point (Upstream)

\begin{tabular}{|c|c|c|c|c|c|c|}
\hline $\begin{array}{c}\text { Sl. } \\
\text { No. }\end{array}$ & Parameters & Minimum & Maximum & Mean & S.D & C.V \\
\hline 01 & Temp ${ }^{\circ} \mathrm{C}$ & 20 & 28 & 23.75 & 1.99 & 0.083 \\
\hline 02 & $\mathrm{pH}$ & 6.30 & 7.90 & 7.19 & 0.411 & 0.057 \\
\hline 03 & TDS mg/L & 780.30 & 1020.0 & 910.05 & 57.75 & 0.063 \\
\hline 04 & TH mg/L & 630.90 & 800.40 & 730.965 & 51.59 & 0.070 \\
\hline
\end{tabular}


IOSR Journal of Engineering

Apr. 2012, Vol. 2(4) pp: 862-882

\begin{tabular}{|c|c|c|c|c|c|c|}
\hline 05 & $\mathrm{Ca} \mathrm{mg} / \mathrm{L}$ & 513.40 & 680.30 & 598.9 & 49.36 & 0.082 \\
\hline 06 & $\mathrm{Mg} \mathrm{mg} / \mathrm{L}$ & 100.70 & 179.00 & 132.065 & 21.36 & 0.161 \\
\hline 07 & $\mathrm{Cl} \mathrm{mg/L}$ & 34.50 & 153.10 & 130.55 & 25.74 & 0.197 \\
\hline 08 & $\mathrm{~F} \mathrm{mg/L}$ & 0.14 & 0.45 & 0.3155 & 0.079 & 0.250 \\
\hline 09 & $\mathrm{SO}_{4} \mathrm{mg} / \mathrm{L}$ & 20.40 & 34.80 & 25.515 & 4.70 & 0.184 \\
\hline 10 & $\mathrm{NO}_{3} \mathrm{mg} / \mathrm{L}$ & 16.90 & 18.80 & 17.90 & 0.58 & 0.032 \\
\hline 11 & $\mathrm{Na} \mathrm{mg} / \mathrm{L}$ & 110.70 & 119.7 & 115.825 & 2.52 & 0.021 \\
\hline 12 & $\mathrm{~K} \mathrm{mg} / \mathrm{L}$ & 17.70 & 24.80 & 20.88 & 1.67 & 0.079 \\
\hline 13 & $\mathrm{HCO} \mathrm{mg} / \mathrm{L}$ & 60.70 & 89.0 & 78.705 & 9.14 & 0.116 \\
\hline 14 & $\mathrm{DO} \mathrm{mg} / \mathrm{L}$ & 5.91 & 8.97 & 7.421 & 0.99 & 0.133 \\
\hline 15 & $\mathrm{BOD} \mathrm{mg} / \mathrm{L}$ & 3.21 & 8.88 & 5.527 & 1.72 & 0.311 \\
\hline 16 & $\mathrm{MPN}$ & 3 & 64 & 14.90 & 13.02 & 0.87 \\
\hline
\end{tabular}

Table 2: Normal Statistics of Water Quality Parameters of Surface Water at sampling point (near Village)

\begin{tabular}{|c|c|c|c|c|c|c|}
\hline $\begin{array}{c}\text { Sl. } \\
\text { No. }\end{array}$ & Parameters & Minimum & Maximum & Mean & S.D & C.V \\
\hline 01 & Temp ${ }^{0} \mathrm{C}$ & 20 & 28 & 23.75 & 1.99 & 0.083 \\
\hline 02 & $\mathrm{pH}$ & 7.42 & 8.14 & 7.79 & 0.222 & 0.028 \\
\hline 03 & $\mathrm{TDS} \mathrm{mg} / \mathrm{L}$ & 832.10 & 1160.30 & 967.60 & 82.58 & 0.085 \\
\hline 04 & $\mathrm{TH} \mathrm{mg} / \mathrm{L}$ & 694.00 & 840.00 & 766.15 & 28.90 & 0.037 \\
\hline 05 & $\mathrm{Ca} \mathrm{mg/L}$ & 540.00 & 680.00 & 648.80 & 29.95 & 0.046 \\
\hline 06 & $\mathrm{Mg} \mathrm{mg} / \mathrm{L}$ & 86.00 & 160.00 & 116.35 & 17.68 & 0.151 \\
\hline 07 & $\mathrm{Cl} \mathrm{mg} / \mathrm{L}$ & 90.00 & 274.00 & 187.60 & 51.87 & 0.276 \\
\hline 08 & $\mathrm{~F} \mathrm{mg/L}$ & 0.11 & 0.87 & 0.543 & 0.21 & 0.403 \\
\hline 09 & $\mathrm{SO}{ }_{4} \mathrm{mg} / \mathrm{L}$ & 32.00 & 168.00 & 89.85 & 37.70 & 0.41 \\
\hline 10 & $\mathrm{NO}_{3} \mathrm{mg} / \mathrm{L}$ & 27.60 & 39.90 & 32.795 & 3.18 & 0.096 \\
\hline 11 & $\mathrm{Na} \mathrm{mg} / \mathrm{L}_{10}$ & 100.00 & 300.00 & 199.00 & 54.76 & 0.275 \\
\hline 12 & $\mathrm{~K} \mathrm{mg} / \mathrm{L}$ & 20.00 & 39.80 & 31.465 & 5.82 & 0.184 \\
\hline 13 & $\mathrm{HCO}_{3} \mathrm{mg} / \mathrm{L}$ & 100.00 & 220.00 & 149.25 & 33.80 & 0.226 \\
\hline 14 & $\mathrm{DO}^{2} \mathrm{mg} / \mathrm{L}$ & 1.45 & 8.14 & 5.823 & 1.62 & 0.278 \\
\hline
\end{tabular}


IOSR Journal of Engineering

Apr. 2012, Vol. 2(4) pp: 862-882

\begin{tabular}{|c|c|c|c|c|c|c|}
\hline 15 & BOD mg/L & 0.77 & 7.5 & 3.974 & 2.22 & 0.559 \\
\hline 16 & MPN & 7 & 120 & 34.45 & 32.09 & 0.931 \\
\hline
\end{tabular}

Table 3: Normal Statistics of Water Quality Parameters of Surface Water at sampling point (Downstream)

\begin{tabular}{|c|c|c|c|c|c|c|}
\hline $\begin{array}{l}\text { Sl. } \\
\text { No. }\end{array}$ & Parameters & Minimum & Maximum & Mean & S.D & C.V \\
\hline 01 & Temp ${ }^{0} \mathrm{C}$ & 20 & 28 & 23.75 & 1.99 & 0.083 \\
\hline 02 & $\mathrm{pH}$ & 7.20 & 8.05 & 7.56 & 0.22 & 0.029 \\
\hline 03 & TDS mg/L & 805.70 & 988.00 & 893.21 & 52.68 & 0.05 \\
\hline 04 & $\mathrm{TH} \mathrm{mg} / \mathrm{L}$ & 647.90 & 791.70 & 736.135 & 33.62 & 0.045 \\
\hline 05 & Ca mg/L & 510.00 & 545.00 & 528.80 & 10.01 & 0.018 \\
\hline 06 & $\mathrm{Mg} \mathrm{mg/L}$ & 131.40 & 246.70 & 207.335 & 29.50 & 0.142 \\
\hline 07 & $\mathrm{Cl} \mathrm{mg/L}$ & 94.60 & 170.80 & 145.905 & 17.18 & 0.117 \\
\hline 08 & F mg/L & 0.27 & 0.492 & 0.348 & 0.062 & 0.178 \\
\hline 09 & $\mathrm{SO}_{4} \mathrm{mg} / \mathrm{L}$ & 30.4 & 39.0 & 33.19 & 2.454 & 0.073 \\
\hline 10 & $\mathrm{NO}_{3} \mathrm{mg} / \mathrm{L}$ & 20.40 & 30.80 & 26.025 & 3.653 & 0.140 \\
\hline 11 & $\mathrm{Na} \mathrm{mg} / \mathrm{L}$ & 85.20 & 109.40 & 95.84 & 8.176 & 0.085 \\
\hline 12 & $\mathrm{~K} \mathrm{mg} / \mathrm{L}$ & 19.2 & 35.2 & 23.40 & 4.40 & 0.188 \\
\hline 13 & $\mathrm{HCO}_{3} \mathrm{mg} / \mathrm{L}$ & 84.90 & 100.40 & 92.225 & 4.782 & 0.051 \\
\hline 14 & $\mathrm{DO} \mathrm{mg} / \mathrm{L}$ & 5.23 & 5.92 & 5.6915 & 0.20 & 0.035 \\
\hline 15 & BOD mg/L & 1.47 & 4.12 & 2.4485 & 0.785 & 0.32 \\
\hline 16 & MPN & 7 & 120 & 34.45 & 32.09 & 0.931 \\
\hline
\end{tabular}

\subsection{Diagrammatic Representation of Geochemical Data:}

\subsubsection{Piper Diagram:}

Further the results of chemical quality of these waters have been plotted in a trilinear diagram, as recommended by piper [8]. In this diagram only the relative proportions of principle cations and anions in terms of percentage epm (equivalent per millions) have been plotted. As shown in (Fig.2, 3 and 4). The diamond shaped field in this diagram has been divided horizontally into two equal triangles. The chemical data of the sample points, fall in the subdivisions of 5,6 \& 9 as is given in Table 4, indicating the secondary alkalinity, secondary salinity and no one cation - anion pair at sampling point (upstream), secondary alkalinity and no one cation - anion pair at sampling point (near village) and secondary alkalinity and no one cation - anion pair at sampling point (downstream). 
IOSR Journal of Engineering

Apr. 2012, Vol. 2(4) pp: 862-882

Table 4: Distribution of Surface Water Samples in the Subdivisions of Piper's Diagram

\begin{tabular}{|l|l|}
\hline Area & Subdivisions \\
\hline 1 & Alkaline earths exceed alkalies \\
\hline 2 & Alkalies exceed alkaline earths \\
\hline 3 & Strong acids exceed weak acids \\
\hline 4 & Weak acids exceed strong acids \\
\hline 5 & Carbonate hardness (secondary alkalinity) exceeds 50 \% \\
\hline 6 & Non-carbonate hardness (secondary salinity) exceeds 50 \\
\hline 7 & Non-carbonate alkali (primary salinity exceeds 50 \% \\
\hline 8 & Narbonate alkali (primary alkalinity) exceeds 50 \% \\
\hline 9 & No one cation-anion pair exceeds 50 \% \\
\hline
\end{tabular}

\subsubsection{Gibb's Diagram:}

Gibb's diagrams [9], representing the ratios of $\mathrm{Na}^{+} /\left(\mathrm{Na}^{+}+\mathrm{Ca}^{2+}\right)$ and $\mathrm{Cl}^{-} /\left(\mathrm{Cl}^{-}+\mathrm{HCO}_{3}\right)$ as a function of TDS, are widely employed to assess the functional sources of dissolved chemical constituents, such as precipitation dominance, rock dominance and evaporation dominance. The chemical data of surface water samples of the area are plotted in Gibb's diagrams (Fig.5, 6 and 7). The distribution of sample points, as shown as a cluster. It is observed that the major part of the study area, surface water contamination is controlled mainly by the rock types as most of the samples fall under rock - dominance class in all sampling points.

\subsubsection{Chadha's Diagram:}

Chadha's diagrams [10] are shown in (Fig.8, 9 and 10). For surface water samples of upstream, near Village and downstream. This is a some what modified version of Piper's diagram. In the Chadha's diagram the difference in milliequivalent percentage between alkaline earth's (calcium plus magnesium) and alkali metals (sodium plus potassium) expressed as percentage reacting values is plotted on the $\mathrm{X}$-axis and the difference in milliequivalent percentage between weak acidic anions (carbonate plus bicarbonate) and strong acidic anions (chloride plus sulphate) is plotted on the Y-axis. The milliequivalent percentage differences between alkaline earths and alkali metals and between weak acidic anions and strong acidic anions would plot in one of the four possible sub-fields of the proposed diagram. In the Chadha's diagram, the square or rectangle field describes the overall character of the water. The diagram can be used to study various hydro chemical processes, such as base cation exchange, cement pollution, mixing of natural waters, sulphate reduction, saline water and other related hydro chemical problems. In the present study, the surface water samples are dominated by two fields. The alkaline earths $\left(\mathrm{Ca}^{++}+\mathrm{Mg}^{++}\right)$exceeded alkali metals $\left(\mathrm{Na}^{+}+\mathrm{K}^{+}\right)$and the strong acidic anions $\left(\mathrm{Cl}^{-}+\mathrm{SO}_{4}{ }^{-}\right)$exceeded weak acidic anions $\left(\mathrm{CO}_{3}^{-}+\mathrm{HCO}_{3}^{-}\right)$. This shows water has temporary hardness in all sampling points. 


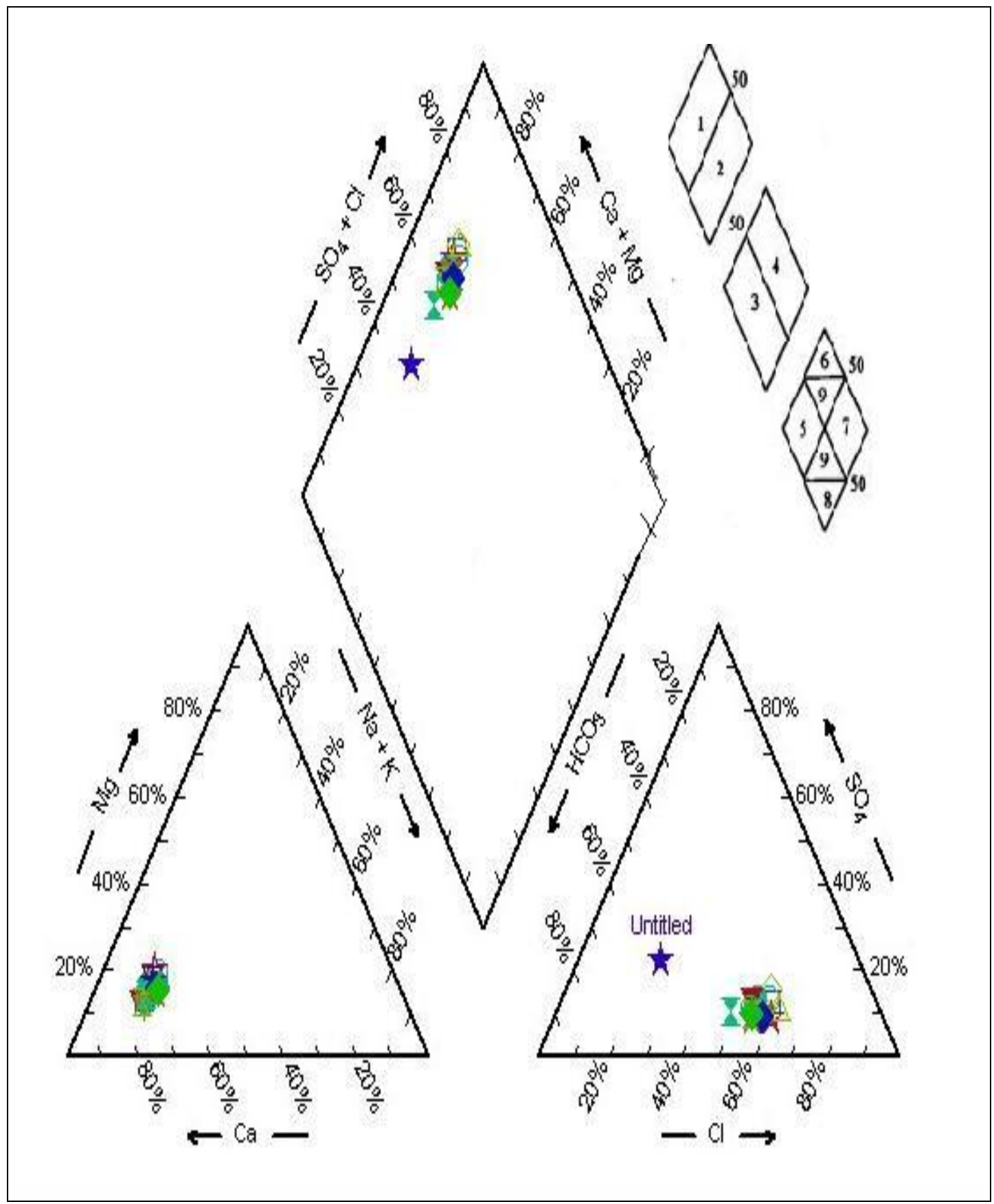

Fig.2. Piper Diagram plotting of Surface water analysis data at sampling point (Upstream) 


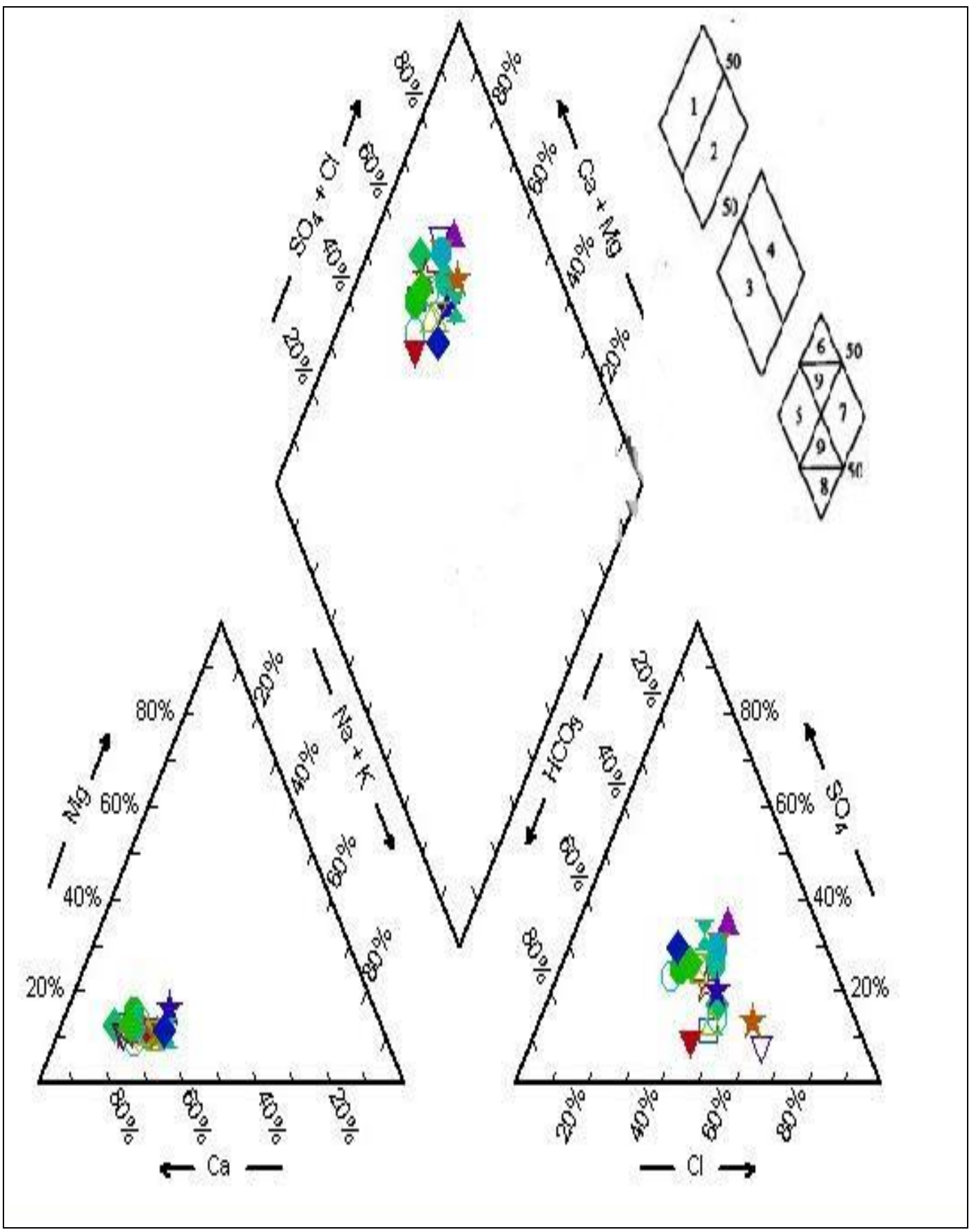

Fig.3. Piper Diagram plotting of Surface water analysis data at sampling point (near Village) 


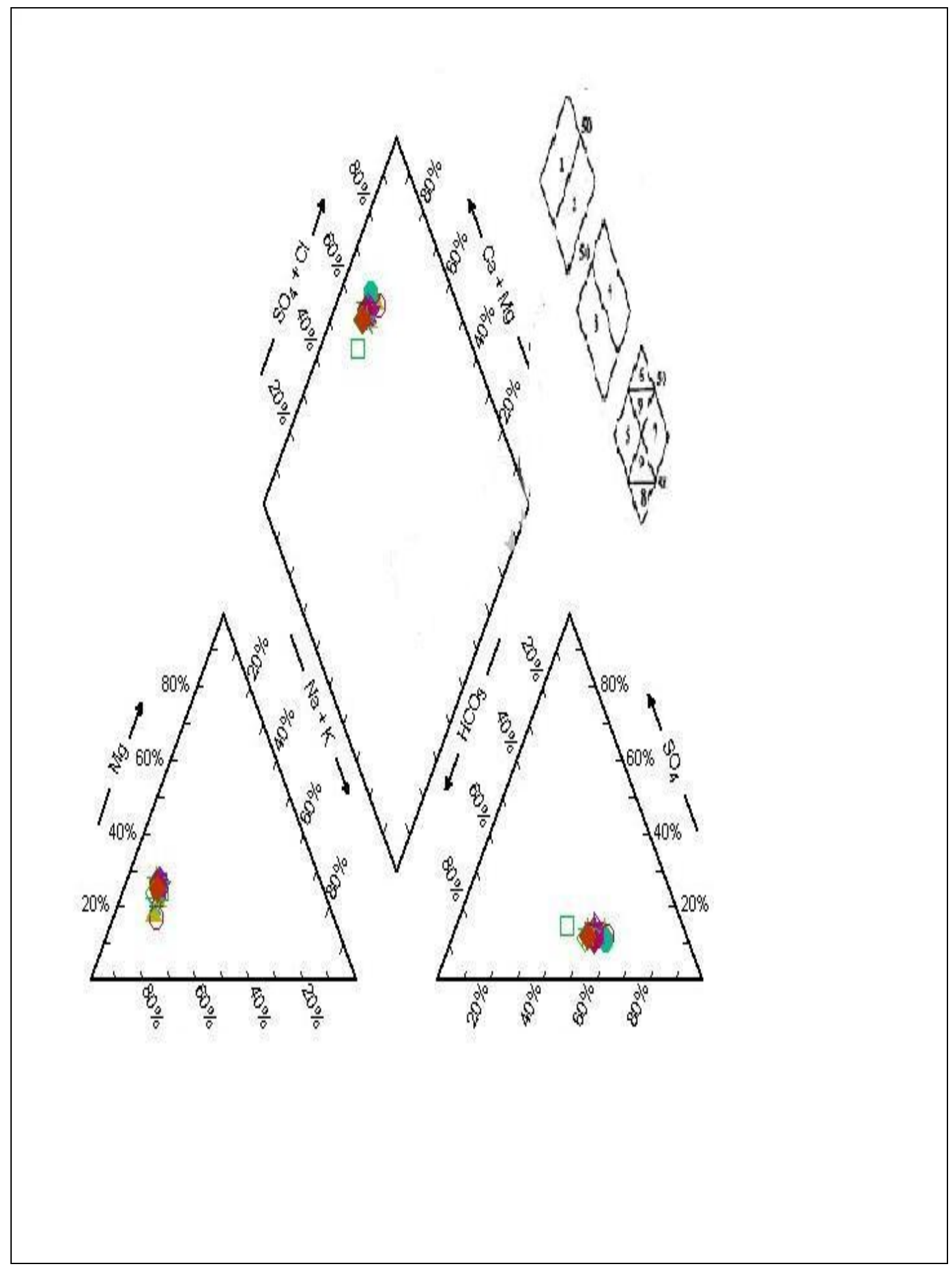

Fig.4. Piper Diagram plotting of Surface water analysis data at sampling point (Downstream) 


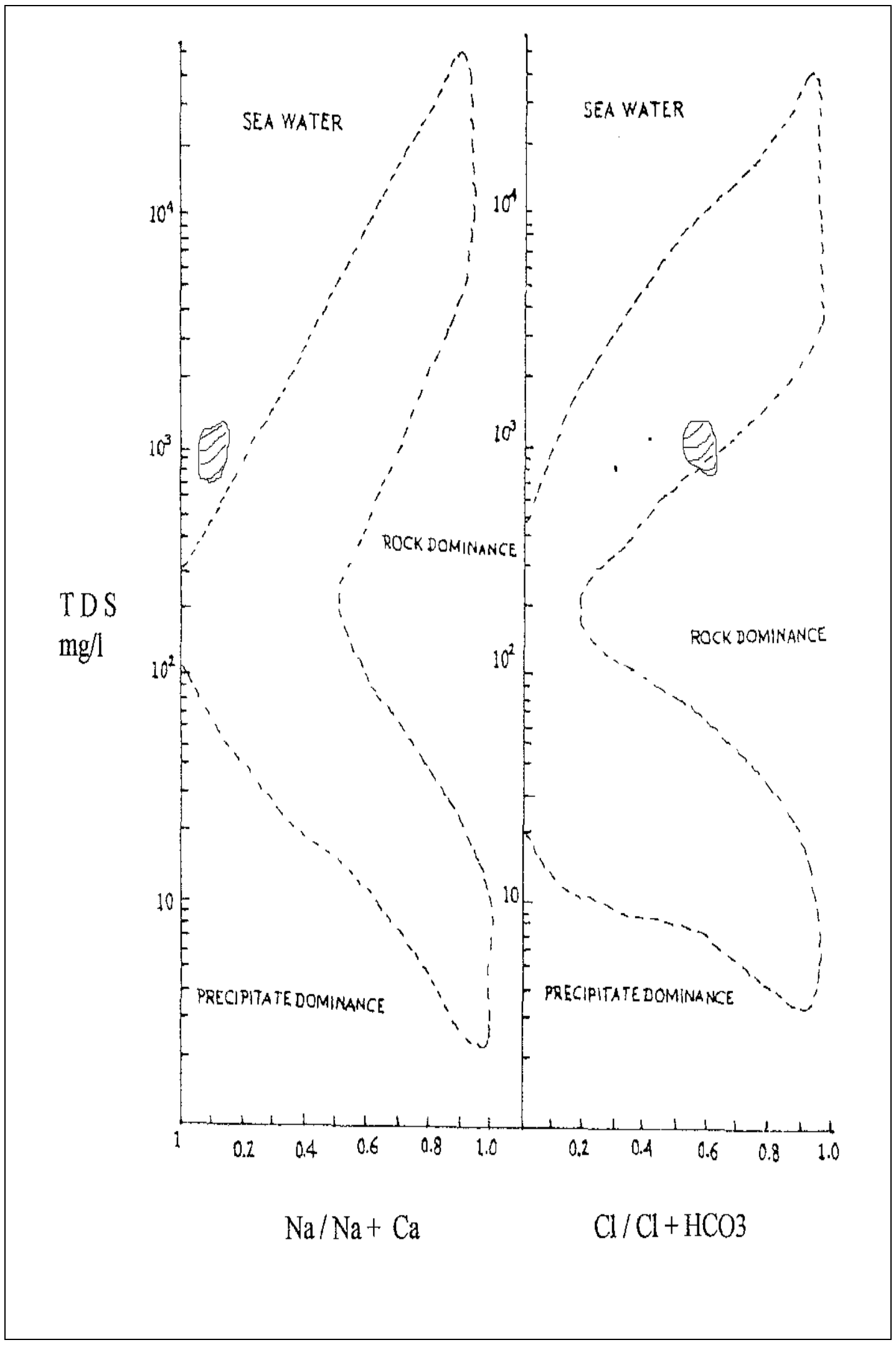

Fig.5. Gibb's Diagram for Bhima River (Upstream) 


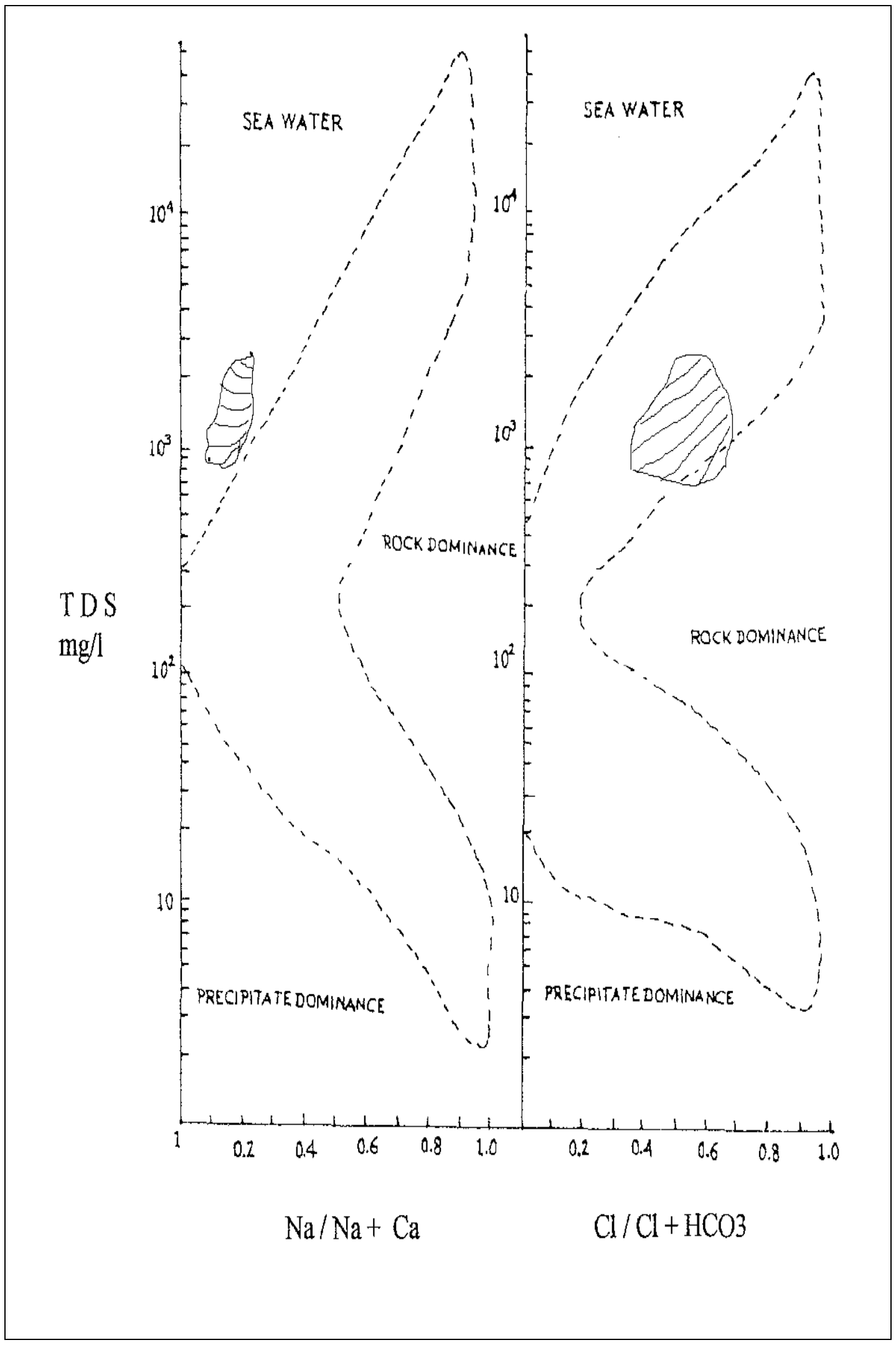

Fig.6. Gibb’s Diagram for Bhima River (Near Village) 


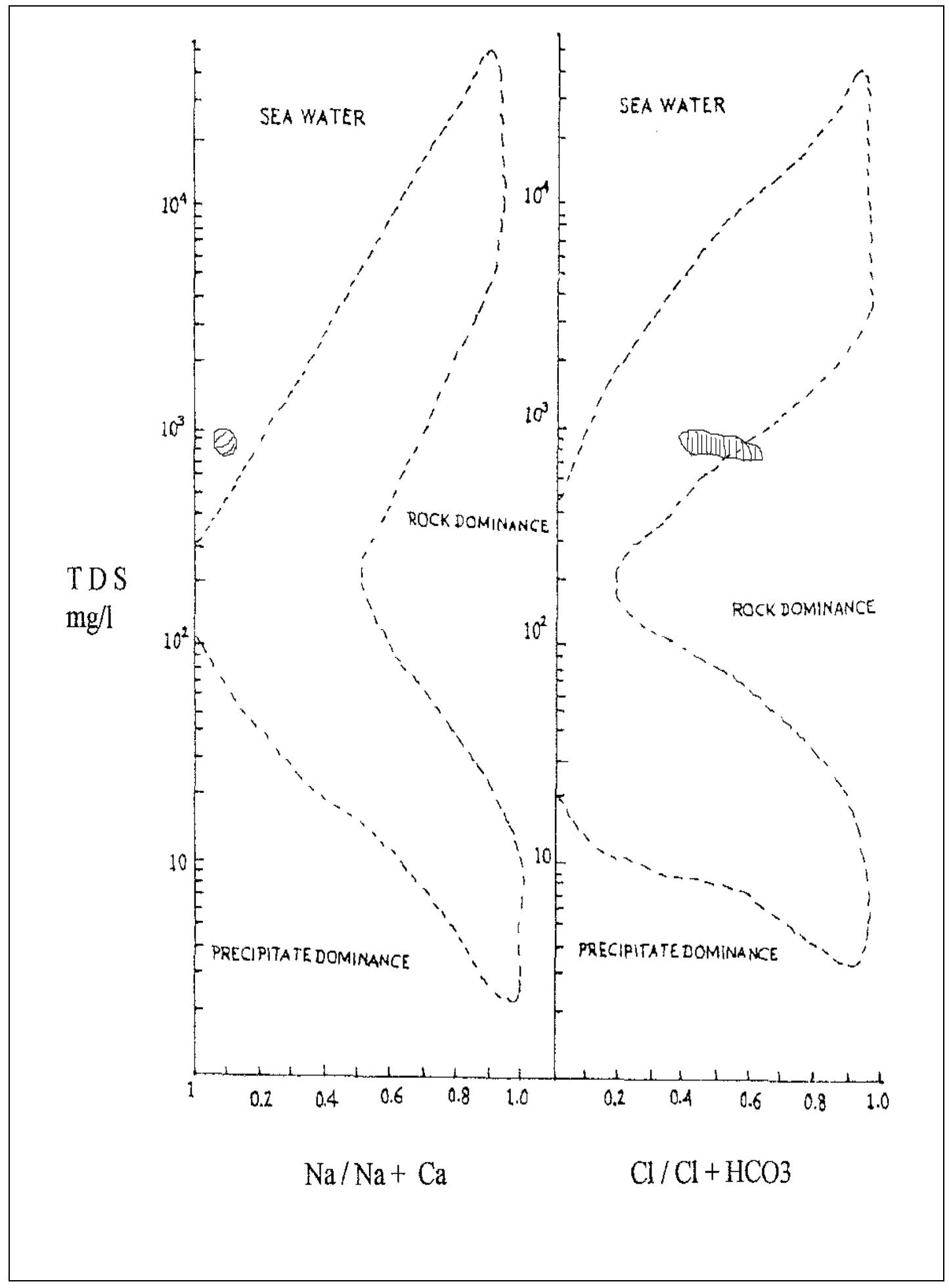

Fig.7. Gibb's Diagram for Bhima River (Downstream) 
IOSR Journal of Engineering

Apr. 2012, Vol. 2(4) pp: 862-882

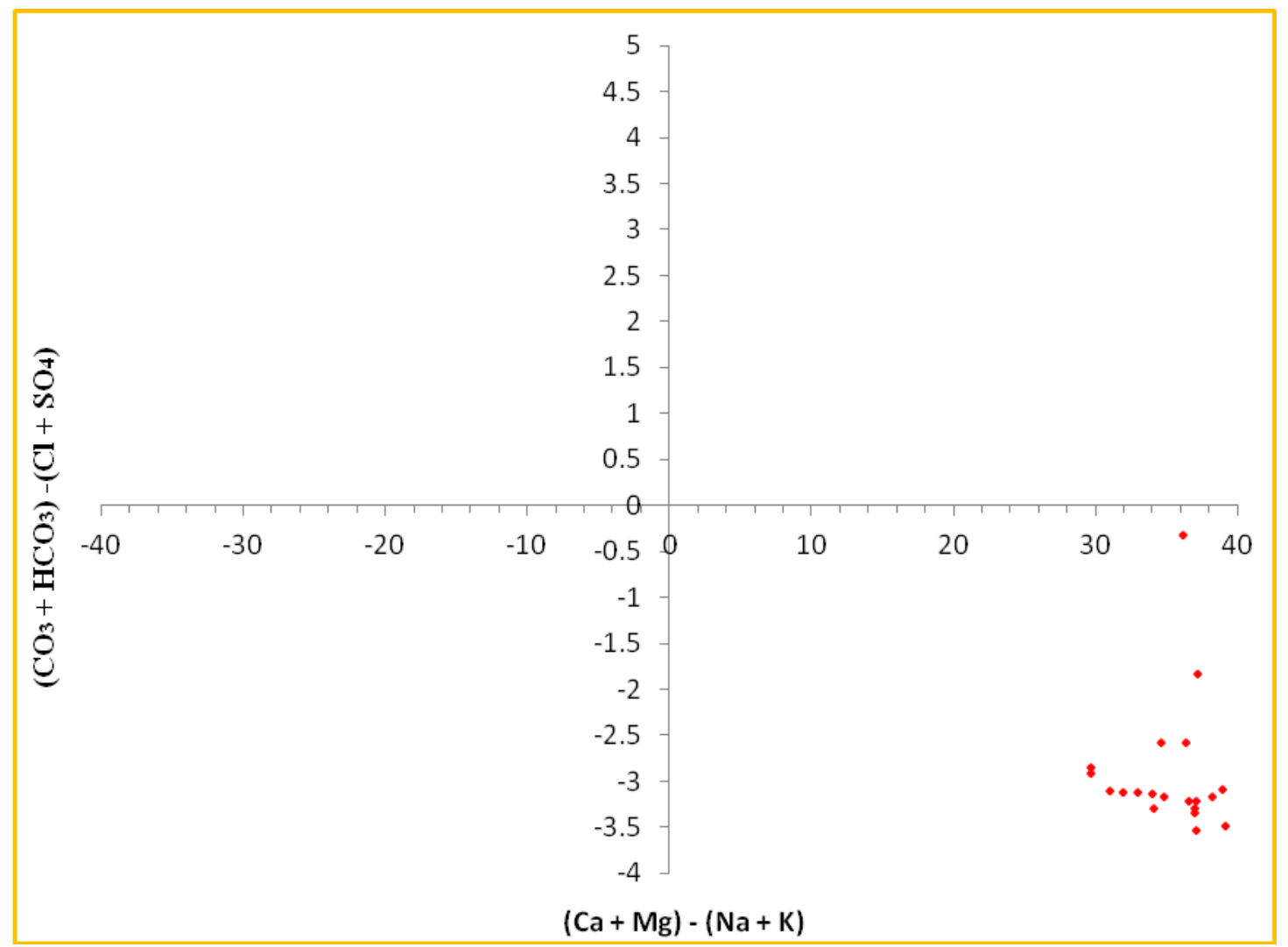

Fig.8: Chadha's Diagram for Surface water Classification (Upstream)

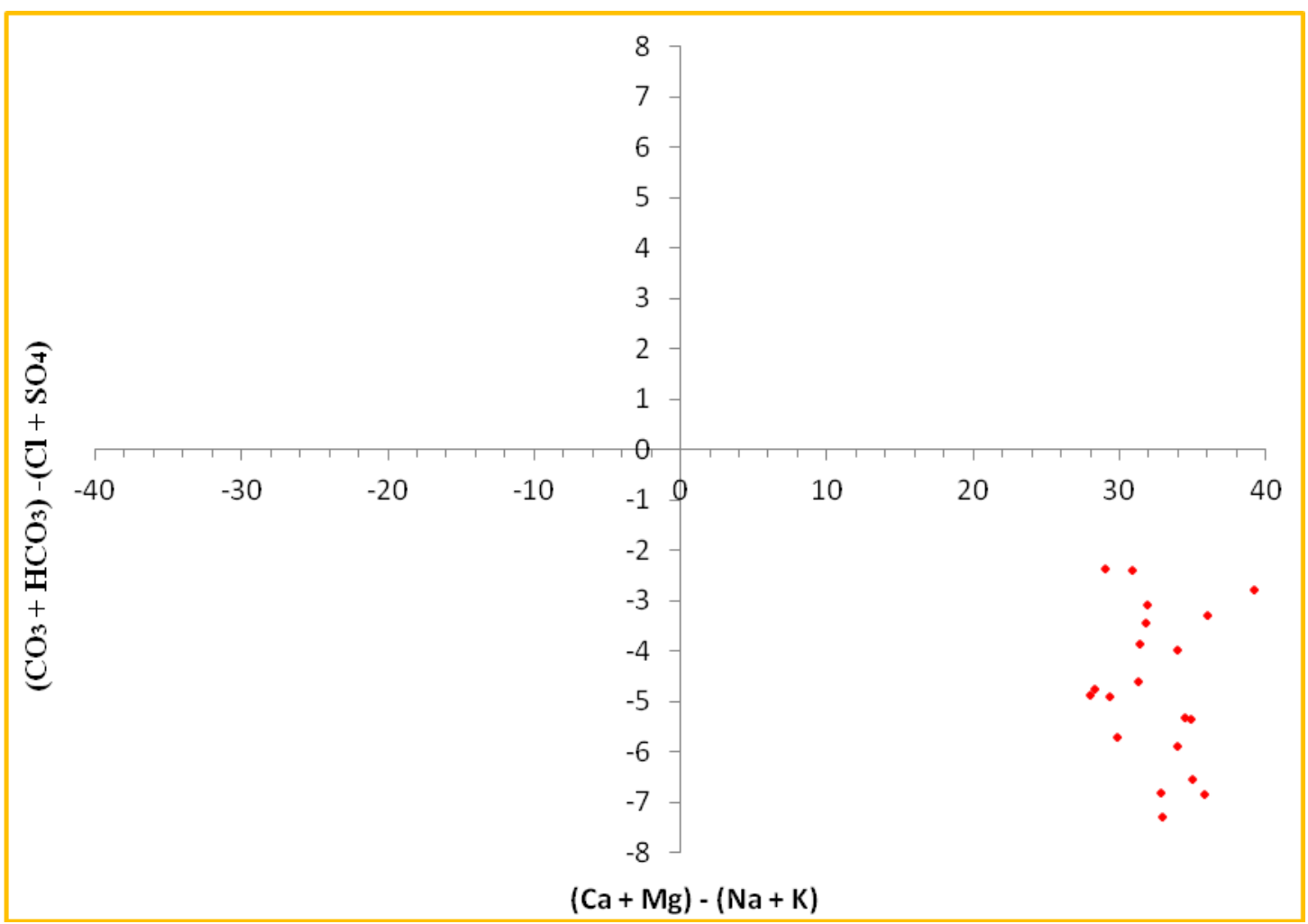

Fig.9: Chadha's Diagram for Surface water Classification (near Village) 
IOSR Journal of Engineering

Apr. 2012, Vol. 2(4) pp: 862-882

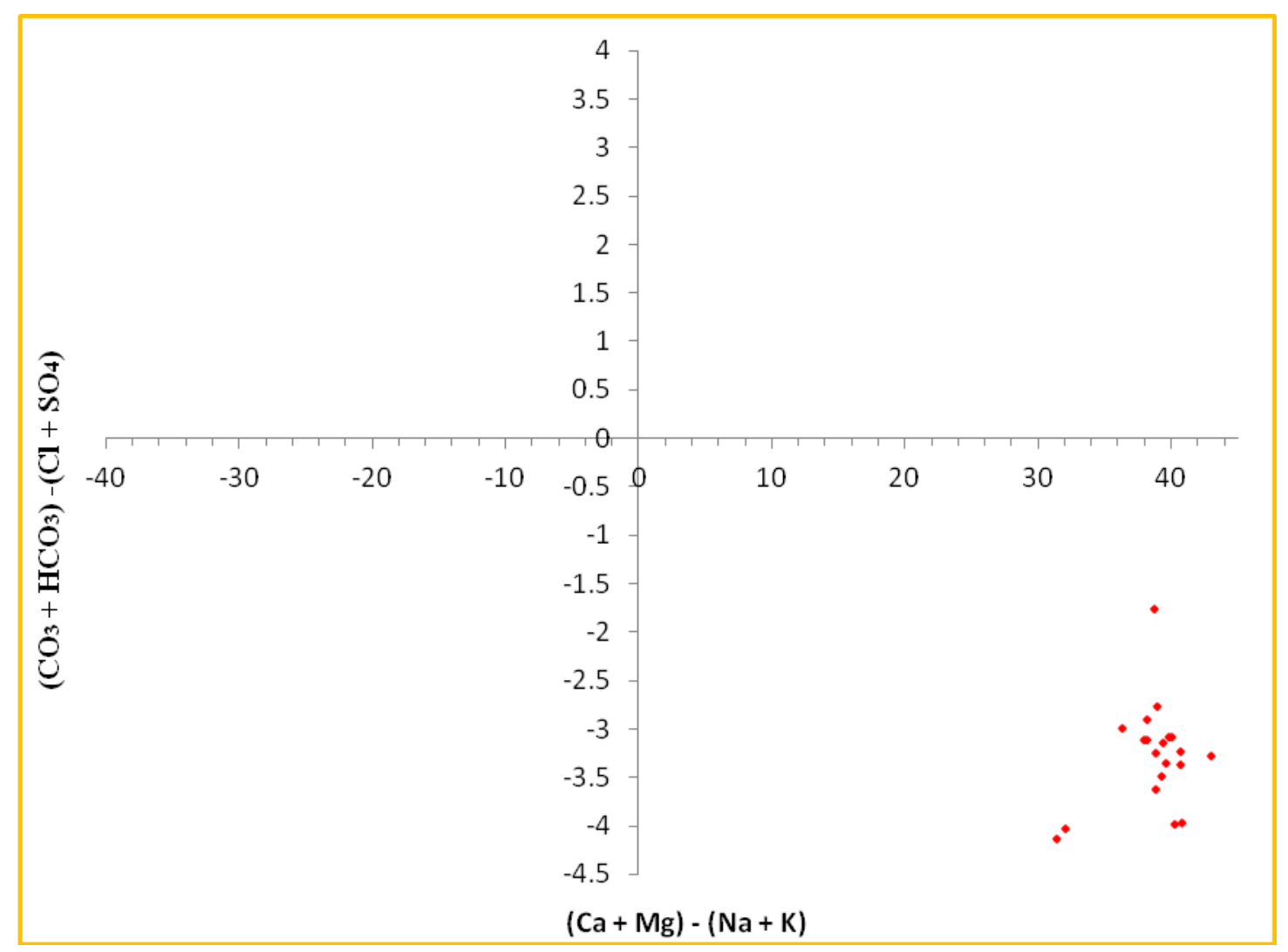

Fig.10: Chadha's Diagram for Surface water Classification (Downstream)

\subsubsection{U.S.Salinity Laboratory Classifications [11]:}

Sodium concentration is an important criterion in irrigation water classification because; sodium reacts with the soil to create sodium hazards by replacing other cations. The extent of this replacement is estimated by Sodium Adsorption Ratio (SAR).

The SAR is calculated from the formula: $\mathbf{S A R}=\mathrm{Na}^{+} /\left[\left(\mathrm{Ca}^{2+}+\mathrm{Mg}^{2+}\right) / 2\right]^{0.5}$

\subsubsection{Sodium Percentage ( $\mathrm{Na} \%)$ :}

Sodium percentage values reflected that the water was under the category of 'good' (20 - $40 \mathrm{Na} \%)$, 'permissible' (40 - $60 \mathrm{Na}$ $\%)$ and 'doubtful' $(60-80 \mathrm{Na} \%)$ class [7].

The Sodium percentage is calculated as: $\mathrm{Na} \%=\mathrm{Na}^{+}+\mathrm{K}^{+} /\left(\mathrm{Ca}^{2+}+\mathrm{Mg}^{2+}+\mathrm{Na}^{+}+\mathrm{K}^{+}\right) * 100$

Here all the concentration is expressed in meq/l. The values of sodium percent are varying from 11.07 to 13.87 in upstream, 11.21 to 24.99 near village point and 8.60 to 12.68 in downstream (Table.5). All the sampling points are in Good categories. When the concentration of sodium ion is high in irrigation water, $\mathrm{Na}^{+}$tends to be absorbed by clay particles, displacing magnesium and calcium ions. The criteria for classification of irrigation water as recommended by the U.S.Salinity laboratory department of agriculture based on the electrical conductivity and SAR value, limits of which have been indicated in Table.6 and 7 below.

\subsubsection{Analysis of Data for Irrigation purposes:}

The US salinity laboratory's diagram [11] is used widely for rating the irrigation waters. SAR is plotted against EC. The plot of chemical data of the surface water samples of the area in the US salinity laboratory's diagram is illustrated in (Fig.11, 12 \& 13). The surface water sample points are as shown as a cluster.

At Upstream: All the samples locations are under $C_{3} S_{1}$ group and hence the surface water of these locations is moderate quality and is suitable for irrigation purposes as is shown in Table.8. 
IOSR Journal of Engineering

Apr. 2012, Vol. 2(4) pp: 862-882

Near Village: All the samples fall in $\mathrm{C}_{3} \mathrm{~S}_{1}$ group and hence the surface water of these locations is moderate quality and is suitable for irrigation purposes as in shown in Table.8.

At Down stream: All the samples fall under $\mathrm{C}_{3} \mathrm{~S}_{1}$ group and hence the surface water of these locations is moderate quality and is suitable for irrigation purposes as is shown in Table.8.

Table 5: SAR and Na\% Values for Surface Water Samples

\begin{tabular}{|c|c|c|c|c|c|c|c|c|c|}
\hline \multirow{2}{*}{ Date } & \multicolumn{3}{|c|}{ Upstream } & \multicolumn{3}{|c|}{ Near Village } & \multicolumn{3}{|c|}{ Downstream } \\
\hline & SAR & $\mathrm{Na} \%$ & EC & SAR & $\mathrm{Na} \%$ & $\mathrm{EC}$ & SAR & $\mathrm{Na} \%$ & $\mathrm{EC}$ \\
\hline Apr-2 & 1.07 & 11.68 & 1353.8 & 1.34 & 14.52 & 1462.1 & 0.86 & 9.39 & 1320.4 \\
\hline Apr-5 & 1.10 & 12.22 & 1380.1 & 1.75 & 17.86 & 1409.3 & 1.00 & 10.89 & 1312.4 \\
\hline Apr-8 & 1.06 & 11.26 & 1387.8 & 1.82 & 18.45 & 1482.1 & 0.98 & 11.33 & 1239.5 \\
\hline Apr-11 & 1.11 & 12.06 & 1422.6 & 0.95 & 11.21 & 1386.0 & 1.10 & 12.68 & 1248.6 \\
\hline Apr-14 & 1.09 & 11.61 & 1383.5 & 1.80 & 17.82 & 1480.6 & 0.98 & 10.67 & 1343.8 \\
\hline Apr-17 & 1.05 & 11.27 & 1407.5 & 1.43 & 14.32 & 1340.4 & 0.99 & 10.49 & 1332.3 \\
\hline Apr-20 & 1.07 & 11.43 & 1458.9 & 2.18 & 20.04 & 1381.8 & 0.83 & 9.27 & 1401.53 \\
\hline Apr-23 & 1.06 & 11.26 & 1400.6 & 1.99 & 19.25 & 1428.7 & 0.89 & 9.75 & 1343.23 \\
\hline Apr-26 & 1.06 & 11.13 & 1338.6 & 1.25 & 14.08 & 1514.0 & 0.86 & 9.30 & 1375.38 \\
\hline Apr-29 & 1.06 & 11.07 & 1336.1 & 1.41 & 14.87 & 1610.0 & 0.80 & 8.74 & 1336.76 \\
\hline May-2 & 1.13 & 12.39 & 1200.4 & 1.53 & 16.02 & 1677.8 & 0.80 & 8.69 & 1380.0 \\
\hline May-5 & 1.09 & 11.78 & 1492.3 & 2.26 & 20.79 & 1553.8 & 0.95 & 10.28 & 1507.69 \\
\hline May-8 & 1.13 & 12.28 & 1307.8 & 1.77 & 16.93 & 1420.1 & 1.00 & 10.72 & 1421.53 \\
\hline May-11 & 1.19 & 13.27 & 1430.7 & 1.67 & 16.27 & 1624.4 & 0.78 & 8.60 & 1520.0 \\
\hline May-14 & 1.22 & 13.87 & 1276.9 & 2.54 & 23.02 & 1642.3 & 0.81 & 8.88 & 1411.23 \\
\hline May-17 & 1.12 & 11.93 & 1354.3 & 2.34 & 22.20 & 1785.0 & 0.84 & 9.90 & 1485.84 \\
\hline May-20 & 1.10 & 11.76 & 1468.7 & 2.84 & 24.99 & 1280.1 & 0.91 & 9.97 & 1335.38 \\
\hline May-23 & 1.11 & 11.81 & 1507.6 & 2.48 & 22.45 & 1365.0 & 0.84 & 10.22 & 1504.61 \\
\hline May-26 & 1.18 & 13.08 & 1569.2 & 2.73 & 23.99 & 1496.9 & 0.80 & 8.95 & 1309.23 \\
\hline May-29 & 1.20 & 13.69 & 1523.3 & 1.57 & 15.39 & 1421.0 & 0.83 & 9.38 & 1354.30 \\
\hline
\end{tabular}


IOSR Journal of Engineering

Apr. 2012, Vol. 2(4) pp: 862-882

Table 6: Showing Water Class for Electrical Conductivity (micromhos/cm)

\begin{tabular}{|c|c|c|}
\hline S1. No. & Water Class & $\begin{array}{c}\text { Electrical Conductivity } \\
(\text { micromhos/cm) }\end{array}$ \\
\hline 1 & Excellent & Less than 250 \\
\hline 2 & Good & $250-750$ \\
\hline 3 & Permissible & $750-2000$ \\
\hline 4 & Doubtful & $2000-3000$ \\
\hline 5 & Unsuitable & More than 3000 \\
\hline
\end{tabular}

Table 7: Showing Water Class for SAR Value

\begin{tabular}{|c|c|c|}
\hline Sl. No. & Water Class & SAR value \\
\hline 1 & Excellent & Less than 10 \\
\hline 2 & Good & $18-18$ \\
\hline 3 & Fair & More than 26 \\
\hline 4 & Poor & \\
\hline
\end{tabular}

Table 8: Salinity Groups of Quality for Irrigation Purposes

\begin{tabular}{|c|c|}
\hline Salinity Groups & Quality for Irrigation purposes \\
\hline $\mathrm{C}_{1} \mathrm{~S}_{1}, \mathrm{C}_{2} \mathrm{~S}_{1}$ & Good \\
\hline $\mathrm{C}_{1} \mathrm{~S}_{2}, \mathrm{C}_{2} \mathrm{~S}_{2}, \mathrm{C}_{3} \mathrm{~S}_{1}, \mathrm{C}_{3} \mathrm{~S}_{2}$ & Moderate \\
\hline All other groups & Bad \\
\hline
\end{tabular}




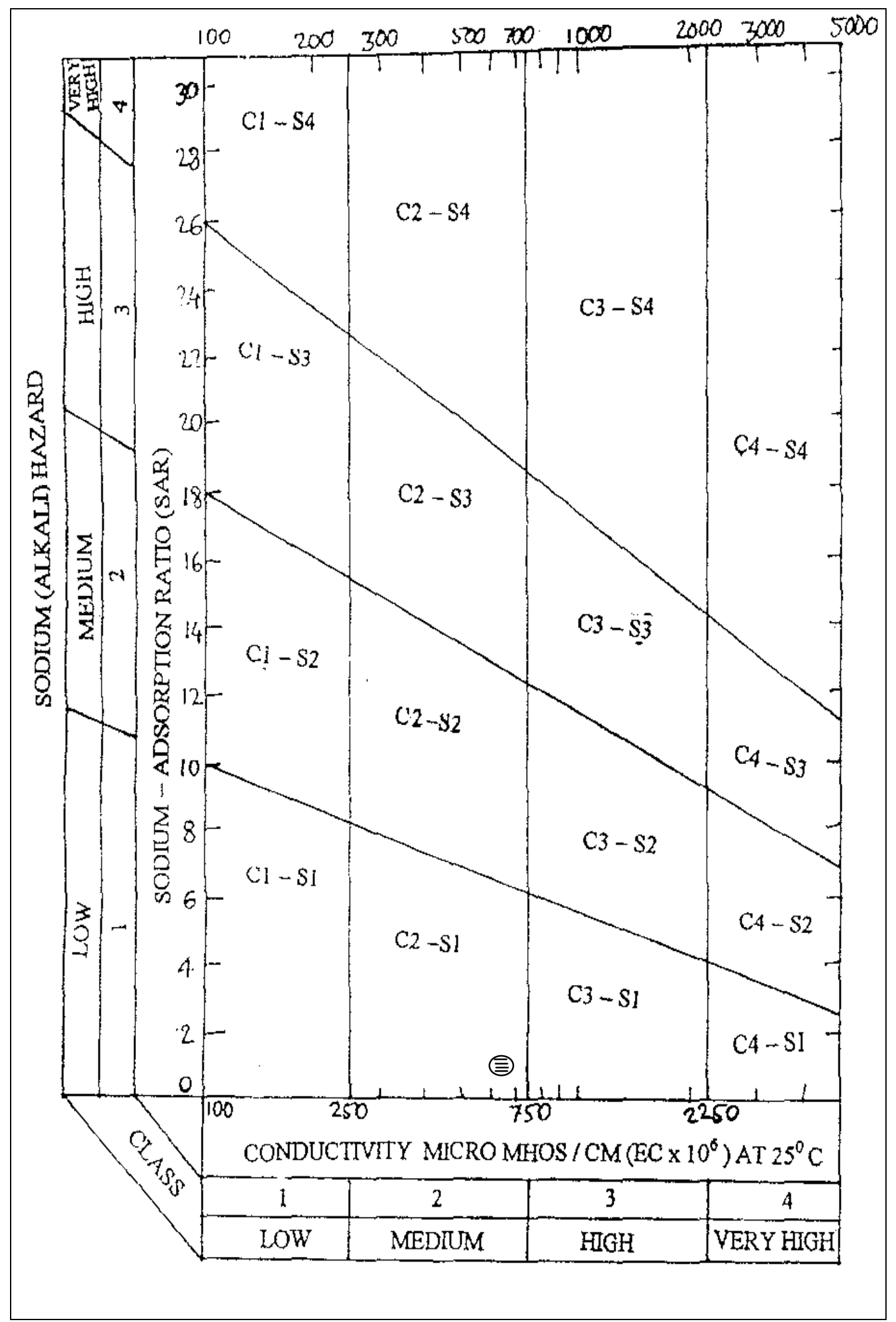

Fig.11: U.S.Salinity Diagram for Irrigation at sampling point (Upstream) 


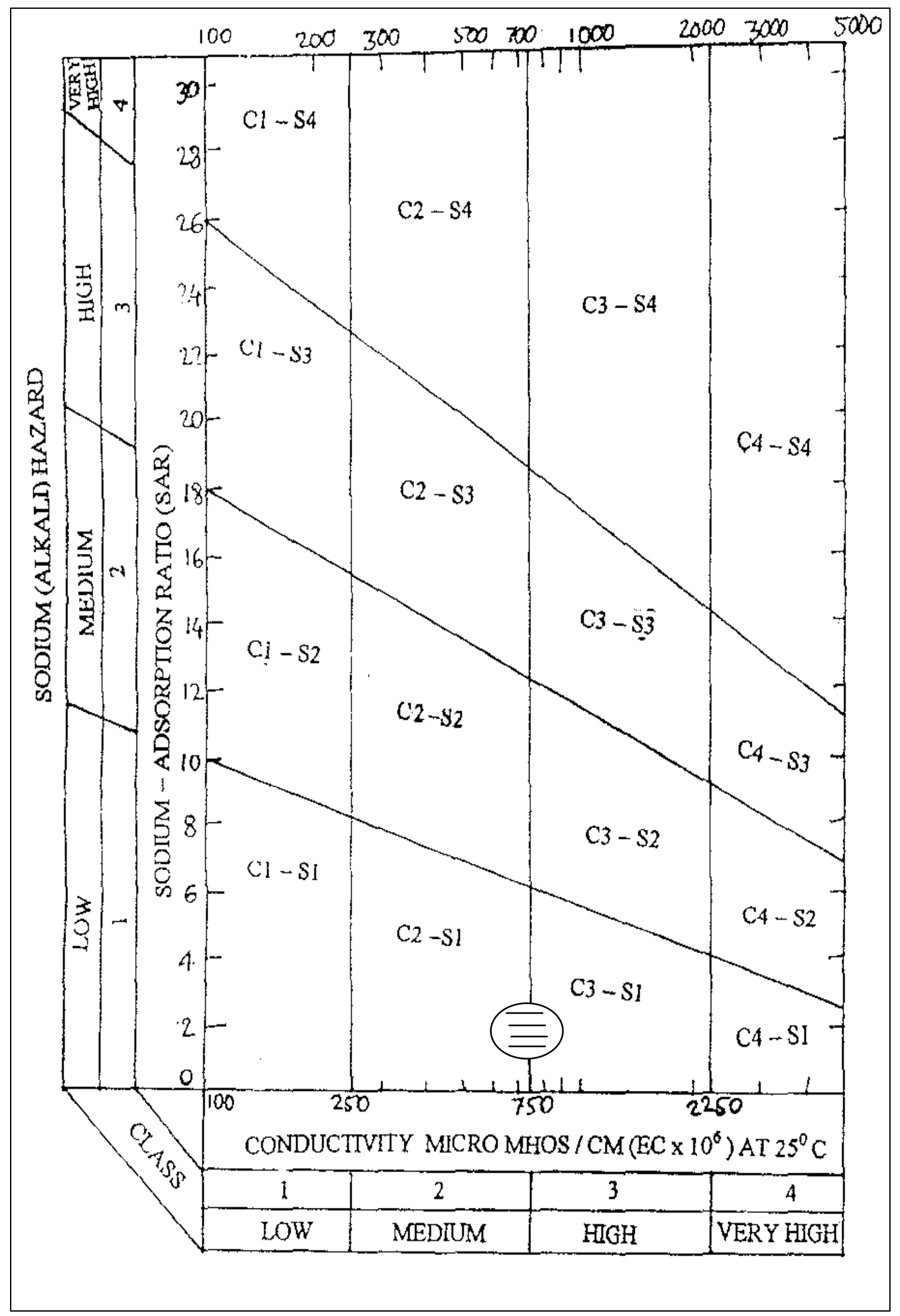

Fig.12: U.S.Salinity Diagram for Irrigation at sampling point (Near Village) 


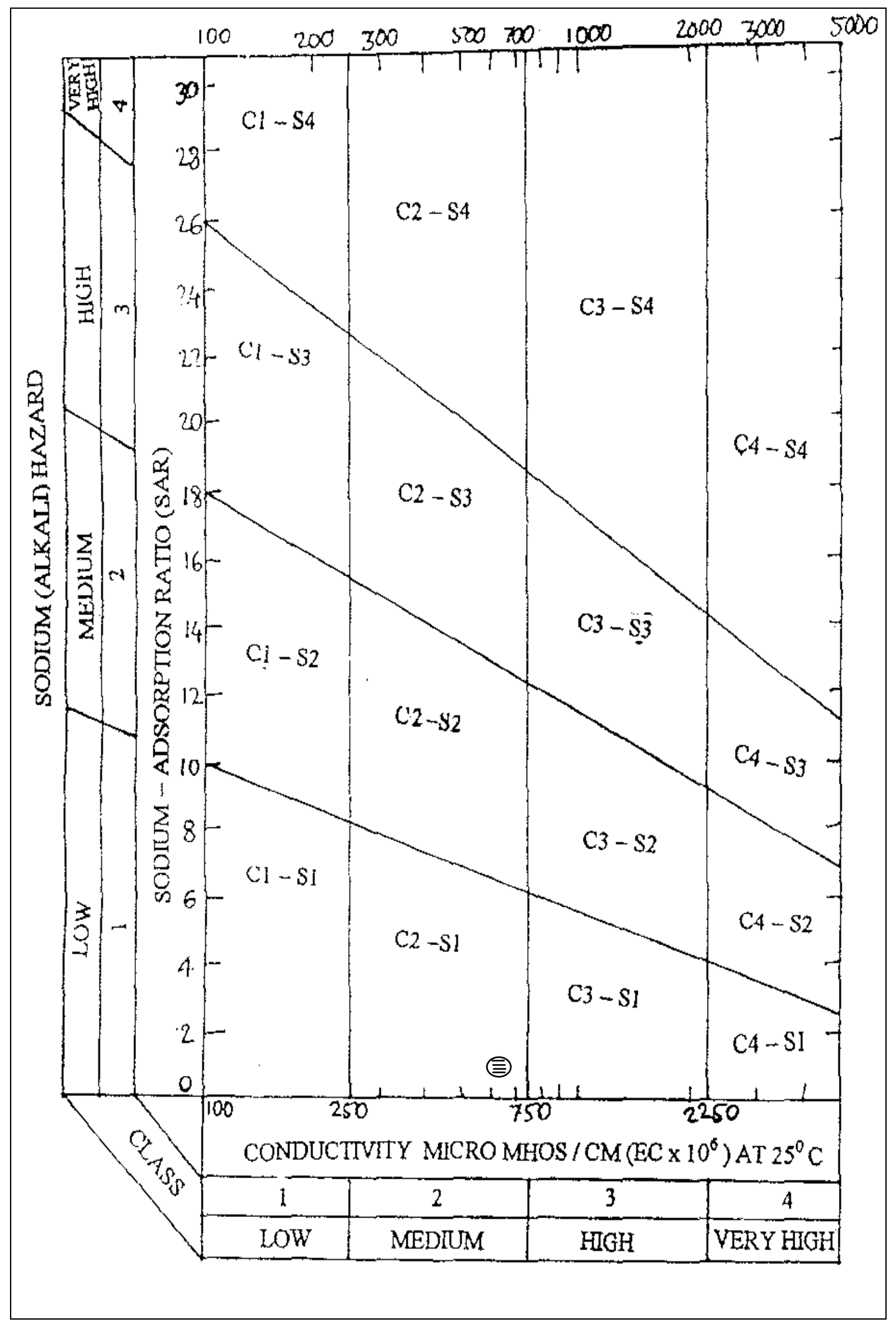

Fig.13: U.S.Salinity Diagram for Irrigation at sampling point (Downstream) 
IOSR Journal of Engineering

Apr. 2012, Vol. 2(4) pp: 862-882

\section{CONCLUSIONS}

After the careful study of analysis interpretation and discussions of the numerical data the conclusions were made. Water is hard in all the sampling points. The concentration of nitrate and fluoride in the area is well within the permissible limit. In the trilinear Piper's diagram, the chemical data of the sampling points as shown fall in the secondary alkaline, secondary saline and no one cation anion pair, indicating that alkalis $\left(\mathrm{Na}^{+}\right.$and $\mathrm{K}^{+)}$are dominating the chemical character of surface water. On the basis of the Gibb's diagram, surface water samples fall under rock dominance class and on the basis of the Chadha's diagram, the surface water samples are temporarily hard. On the basis of the US Salinity Laboratory diagram, the surface water samples are of moderate quality for irrigation. $\mathrm{Na} \%$ is within the limit of $60 \%$ and hence suitable for irrigation in the study area. From the geochemical classification of water, it is evident that, all the samples are quite suitable for Irrigation.

\section{ACKNOWLEDGEMENTS}

Thanks to the "Hyderabad Karnataka Education Society Gulbarga", Karnataka State, India.

\section{REFERENCES}

1. Shivashranappa et al., (2012), Study on the physico-chemical characteristics of groundwater of Bidar city and its industrial area, IJABT, Vol. No.3, Issue No.1, 2

2. Nirdosh Patil, et al., (2010), "Study on the Physico-Chemical characteristics of ground water of (Karnataka)" International Journal of Applied Biology \& Pharmaceutical Technology, 1(2), Aug-Oct, 519

3. Agarwal D.K et al, (1976), "Physico-chemical Characters of the Ganges at Varanasi", Indian Journal of Environmental Health, 18, 201-206

4. APHA (American Public Health Association), (2003), Standard methods for examination of water and wastewater specifications, Washington DC, $6,19^{\text {th }}$ edition.

5. WHO (World Health Organization), (1993), Guidelines for drinking water quality, $2^{\text {nd }}$ Edition, $1,188$.

6. Bureau of Indian Standards, (1993), (IS 10500:1991), Edition 2.1

7. N.Subba Rao, (2006), Seasonal Variation of Groundwater Quality in a part of Guntur District, Andhra Pradesh, India.

8. Environ Geol 49; $413-429$.

a. 8. Piper AM, (1944), a graphic procedure in the geochemical interpretation of water analyses, Am Geophy Union Trans 25: 914 - 923.

9. Gibb's R.J (1970). Mechanisms controlling world water chemistry. Science 17: 1088 - 1090.

10. Chadha's D.K (1999). A proposed new diagram for geochemical classification of natural waters and interpretation of chemical data.

11. US Salinity Laboratory staff (1954). Diagnosis and improvement of saline and alkali soils. US Department of Agricultural Hand Book 60, Washington. 